(c) American Dairy Science Association, 2003.

\title{
Quantitative Trait Loci Mapping of Functional Traits in the German Holstein Cattle Population
}

\author{
Ch. Kühn, ${ }^{\star}$ J. Bennewitz,† N. Reinsch,† N. Xu,† H. Thomsen,† C. Looft,† G. A. Brockmann, ${ }^{\star}$ M. Schwerin, ${ }^{\star}$ \\ C. Weimann,‡ S. Hiendleder,‡ G. Erhardt,‡ I. Medjugorac,§ M. Förster,§ B. Brenig,\| F. Reinhardt,\# \\ R. Reents,\# I. Russ, ${ }^{\star \star}$ G. Averdunk,†† J. Blümel,ł‡ and E. Kalm† \\ *Forschungsinstitut für die Biologie landwirtschaftlicher Nutztiere, D-18196 Dummerstorf, Germany \\ †Institut für Tierzucht und Tierhaltung, Christian-Albrechts-Universität, D-24098 Kiel, Germany \\ †Institut für Tierzucht und Haustiergenetik der Justus-Liebig-Universität, D-35390 Gießen, Germany \\ §Institut für Tierzucht der Ludwig-Maximilians-Universität, D-80539 München, Germany \\ ||Institut für Veterinärmedizin der Georg-August-Universität, D-37073 Göttingen, Germany \\ \#Vereinigte Informationssysteme Tierhaltung w.V., D-27283 Verden, Germany \\ **Tierzuchtforschung e.V., D-85586 Grub, Germany \\ ††Bayerische Landesanstalt für Tierzucht, D-85586 Grub, Germany \\ łłInstitut für die Fortpflanzung landwirtschaftlicher Nutztiere, D-16321 Schönow, Germany
}

\begin{abstract}
A whole-genome scan to detect quantitative trait loci (QTL) for functional traits was performed in the German Holstein cattle population. For this purpose, 263 genetic markers across all autosomes and the pseudoautosomal region of the sex chromosomes were genotyped in 16 granddaughter-design families with 872 sons. The traits investigated were deregressed breeding values for maternal and direct effects on dystocia $\left(\mathrm{DYS}_{\mathrm{m}}, \mathrm{DYS}_{\mathrm{d}}\right)$ and stillbirth $\left(\mathrm{STI}_{\mathrm{m}}, \mathrm{STI}_{\mathrm{d}}\right)$ as well as maternal and paternal ef-

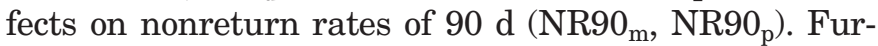
thermore, deregressed breeding values for functional herd life (FHL) and daughter yield deviation for somatic cell count (SCC) were investigated. Weighted multimarker regression analyses across families and permutation tests were applied for the detection of QTL and the calculation of statistical significance. A ten percent genomewise significant QTL was localized for $\mathrm{DYS}_{\mathrm{m}}$ on chromosome 8 and for SCC on chromosome 18. A further 24 putative QTL exceeding the 5\% chromosomewise threshold were detected. On chromosomes 7, $8,10,18$, and $\mathrm{X} / \mathrm{Y}_{\mathrm{ps}}$, coincidence of QTL for several traits was observed. Our results suggest that loci with influence on udder health may also contribute to genetic variance of longevity. Prior to implementation of these QTL in marker assisted selection programs for functional traits, information about direct and correlated effects of these QTL as well as fine mapping of their chromosomal positions is required.
\end{abstract}

(Key words: quantitative trait loci, functional traits, Holstein cattle)

\footnotetext{
Received May 13, 2002.

Accepted August 9, 2002.

Corresponding author: Christa Kühn; e-mail: kuehn@ fbn-dummerstorf.de.
}

\begin{abstract}
Abbreviation key: ADR $=$ German Cattle Breeders Federation, BTA = Bos taurus chromosome, $\mathbf{C V M}=$ complex vertebral malformation, DYD = daughter yield deviation, $\mathbf{D Y S}_{\mathrm{d}}=$ dystocia (direct effect), $\mathbf{D Y} \mathbf{S}_{\mathrm{m}}=$ dystocia (maternal effect), $\mathbf{F H L}=$ functional herd life, MAS = marker assisted selection, $\mathbf{N R 9 0}_{\mathrm{m}}=$ nonreturn rate of $90 \mathrm{~d}$ (maternal effect), $\mathbf{N R 9 0}_{\mathrm{p}}=$ nonreturn rate of $90 \mathrm{~d}$ (paternal effect), REBV = relative estimated breeding value, SSCP = single strand conformation polymorphism, $\mathbf{S T I}_{\mathrm{d}}=$ stillbirth (direct effect), $\mathbf{S} \mathbf{T I} \mathbf{m}_{\mathrm{m}}=$ stillbirth (maternal effect), $\mathbf{X} / \mathbf{Y}_{\mathrm{ps}}=$ pseudoautosomal region of the sex chromosomes.
\end{abstract}

\section{INTRODUCTION}

Functional traits are defined as those characteristics of an animal, which increase the efficiency by reducing costs of input (Groen et al., 1997). Modern milk production management increasingly focuses on functional traits like longevity, udder health, or fertility. However, during the last decades, strong selection of milk production traits was accompanied by a decrease in performance with respect to longevity and by detrimental effects on fertility and udder health (Dürr et al., 1997; Essl, 1997; Royal et al., 2000). This problem is further underlined by numerous reports about unfavorable genetic correlations between milk performance traits and functional traits (e.g. Simianer et al., 1991; Castillo-Juarez et al., 2000). In addition to the direct impact of functional traits on the economic efficiency of dairy cattle farming (Vollema et al., 2000), there is an increasing public concern regarding animal welfare, which is closely related to functional traits (Groen et al., 1997). However, many functional traits are difficult to describe and to record in a dairy cattle population. For calving ease, as an example, only subjective scores are available. For other traits, like disease incidence, there is no direct 
recording in many countries at all. In these cases, only indirect selection is possible through the use of information on index traits like SCC as an indicator for udder health (Lund et al., 1994). These difficulties in trait recording and, additionally, the low heritability of functional traits, impede progress of conventional breeding schemes for functional traits. Marker assisted selection (MAS) may provide a tool to improve this situation. In dairy cattle populations QTL influencing milk production traits are increasingly elucidated (e.g. Georges et al., 1995; Kühn et al., 1999; Grisart et al., 2002). However, only limited data are available on the genetic background of health traits and functional traits like fertility or longevity in spite of their economic impact especially in modern production systems. Concerning udder health, several studies described QTL for SCC (e.g. Ashwell et al., 1997; Heyen et al., 1999; Schrooten et al., 2000; Van Tassel et al., 2000) and QTL for mastitis (Klungland et al., 2001). However, QTL for calving and fertility traits in dairy cattle had only been described by Schrooten et al. (2000). Indications of QTL for longevity were found by studies of Ashwell et al. (1998a; 1999) and Van Tassel et al. (2000) in the US Holstein population.

In order to increase the knowledge of the genetic background of this important class of traits, an attempt was made to detect functional trait QTL contributing to the genetic variation in calving ease, frequency of stillbirth, nonreturn rate of $90 \mathrm{~d}$, functional longevity, and somatic cell count. For this purpose, we set up a whole-genome scan to map QTL for functional traits in a granddaughter design in German Holsteins. Calving ease and stillbirth were investigated by analyzing direct effect QTL and maternal effect QTL; fertility was investigated by analyzing QTL for male and female effects on a nonreturn rate of 90 .

\section{MATERIALS AND METHODS}

\section{Animals}

The pedigree material included 16 paternal half-sib families from the German Holstein breed with a total of 872 bulls. This granddaughter design (Weller et al., 1990) was part of a collaborative QTL research effort of German AI and breeding organizations, scientific institutes for animal breeding, and animal computing centers initiated by the German cattle breeders' federation (ADR). Fourteen of the grandsires in the half sib-families were themselves sons of three great-grandsires, which were also available for genotyping to increase marker informativity. Numbers of sons per grandsire ranged from 19 to 127 , with an average family size of 54.5 sons.

\section{Markers and Maps}

A whole genome scan, covering all autosomes [Bos taurus chromosomes (BTA) 1-29] and the pseudoautosomal region of the sex chromosomes (BTAX/Y $\mathbf{Y}_{\mathbf{p s}}$ ), was applied to the pedigree material (Thomsen et al., 2000). The marker set included 246 microsatellite markers, eight single strand conformation polymorphisms (SSCP), four protein polymorphisms, and five erythrocyte antigen loci from published marker maps. Microsatellite and SSCP genotypes were determined by automated fragment analysis (A.L.F. express, Amersham-Pharmacia; ABI377, Perkin-Elmer) or detection of microsatellite PCR fragments by silver staining (Weikard et al., 1997). Routine blood typing laboratories determined genotypes for erythrocyte antigen genotypes according to standard procedures. All genotypes were read into the ADR database (Reinsch, 1999) and checked for Mendelian inheritance. Marker maps were calculated using the multipoint option of CRIMAP (Green et al., 1990) and have been published previously in detail by Thomsen et al. (2000). These calculated marker orders and map distances were used in the QTL analysis.

\section{Phenotypic Data}

Phenotypic traits considered were stillbirth [effect of calf (direct effect; $\mathbf{S T I}_{\mathbf{d}}$ ) and effect of mother of calf (maternal effect; $\mathbf{S T I}_{\mathbf{m}}$ )], dystocia [effect of calf (direct effect; $\mathbf{D Y S}_{\mathbf{d}}$ ) and effect of mother of calf (maternal effect; $\mathbf{D Y S}_{\mathbf{m}}$ )], nonreturn rate of $90 \mathrm{~d}$ [effect of sire (paternal effect; $\mathbf{N R 9 0}_{\mathbf{p}}$ ) and effect of the cow (maternal effect; $\mathbf{N R 9 0}_{\mathbf{m}}$ )], functional herd life (FHL), and SCC. Data on stillbirth were generated by on-farm scoring (1-5) by the farmer, who also indicated stillbirth (death of calf at birth or within $24 \mathrm{~h}$ postpartum) to the central database at the animal computing centers for calculation of estimated breeding values. Nonreturn rate of $90 \mathrm{~d}$ was calculated from data entry about repetitive breeding after first insemination within a time period of $90 \mathrm{~d}$. Functional herd life was calculated by survival analysis (Ducrocq and Sölkner, 1994) and adjusted for relative milk yield within herd. Data on SCC are collected together with the monthly routine milk-recording scheme. Since no direct data on mastitis incidence in Germany are available, SCC is taken as indirect indicator of udder health (Reents, 1995). The total number of daughters (for the analysis of SCC), calvings (for the analysis of calving traits), inseminations (for the analysis of fertility traits), and the number of daughters with first lactation (for the analysis of FHL) in the data set as well as the respective number per sire are listed in Table 1.

EBV for functional traits of sons were calculated by using a BLUP animal model. For calving traits (DYS, STI) and fertility traits (NR90), maternal effect and di- 
Table 1. Description of traits included in the analysis. Sum: total number of observations in the analysis; Min: minimal number of observations per son; Max: highest number of observations per son; Average: arithmetic mean of observations per son; Median: median of observations per son, $\mathrm{h}^{2}$ : heritability used in the national evaluation procedure and for weighting in the regression analysis of this study.

\begin{tabular}{|c|c|c|c|c|c|c|c|}
\hline Trait & Observation & Sum & Min & Max & Average & Median & $\mathrm{h}^{2}$ \\
\hline SCC & SCC of daughters & 659,879 & 7 & 28,547 & 755 & 172 & 0.10 \\
\hline $\mathrm{DYS}_{\mathrm{d}}$ & Births of offspring & $2,112,756$ & 61 & 85,530 & 2460 & 477 & 0.05 \\
\hline $\mathrm{STI}_{\mathrm{d}}$ & Births of offspring & $2,112,756$ & 61 & 85,530 & 2460 & 477 & 0.05 \\
\hline $\mathrm{DYS}_{\mathrm{m}}$ & Calvings of daughters & 952,923 & 71 & 43,787 & 1099 & 341 & 0.05 \\
\hline $\mathrm{STI}_{\mathrm{m}}$ & Calvings of daughters & 952,923 & 71 & 43,787 & 1099 & 341 & 0.05 \\
\hline $\mathrm{NR} \mathrm{p}_{\mathrm{p}}$ & Inseminations & $3,290,801$ & 55 & 247,159 & 4048 & 665 & 0.02 \\
\hline $\mathrm{NR} 90_{\mathrm{m}}$ & Inseminations of daughters & $1,404,842$ & 163 & 62,320 & 1756 & 514 & 0.02 \\
\hline FHL & Daughters & 555,971 & 34 & 22,305 & 428 & 128 & 0.10 \\
\hline
\end{tabular}

rect (DYS, STI) or paternal (NR90) effect were estimated simultaneously, assuming a correlation of -0.1 between maternal and direct/paternal effect. For all traits except SCC, relative estimated breeding values were provided for the QTL analysis. For SCC, daughter yield deviations (DYD, Van Raden and Wiggans, 1991) from the first lactation were available for the analysis. DYD for SCC were calculated by a test day animal model. All data were taken from the national breeding value evaluation in November 1999. For QTL analysis, breeding values were deregressed by dividing each estimated breeding value by the square of its reliability:

$$
\operatorname{Dereg}_{\mathrm{i}}=\left(1 / \mathrm{r}_{\mathrm{i}}^{2}\right) \mathrm{REBV}_{\mathrm{i}}
$$

where Dereg $_{i}$ is the deregressed estimated breeding value of son $i, R E B V_{i}$ is the relative estimated breeding value of son $i$, and $r_{i}^{2}$ is the reliability of the REBV of son i.

For QTL analysis, all sons of a sire with data on REBV/ DYD for the functional traits were included irrespective of available genotypes at the genetic markers to improve calculation of grandsire effects.

\section{QTL Analysis}

QTL mapping was performed for each trait separately by a weighted multimarker regression analysis (Knott et al., 1996) across all families with the BIGMAP and ADRQTL software. The programs are available to the scientific community (please contact: nreinsch@tierzuch t.uni-kiel.de).

$$
\mathrm{y}_{\mathrm{ijk}}=\mathrm{gs}_{\mathrm{i}}+\mathrm{b}_{\mathrm{ik}} \times \mathrm{P}_{\mathrm{ijk}}+\mathrm{e}_{\mathrm{ijk}}
$$

where $y_{i j k}$ is the trait value of the jth son of the ith grandsire, $\mathrm{gs}_{\mathrm{i}}$ is the fixed effect of the ith grandsire, $\mathrm{b}_{\mathrm{ik}}$ is the regression coefficient for the ith grandsire at the kth chromosomal location, $\mathrm{P}_{\mathrm{ijk}}$ is the probability of the jth son receiving the chromosomal segment for gamete one from the ith grandsire at the kth chromosomal position, and $\mathrm{e}_{\mathrm{ijk}}$ is the random residual. The weight of each observation was proportional to one over the variance of a half-sib mean. This variance was calculated as

$$
w^{-1}=\left(\frac{1+0.25 h^{2}(n-1)}{n}\right) \cdot \sigma_{p}^{2}
$$

where $\mathrm{h}^{2}$ is the heritability of the trait (Table 1 ), $\sigma^{2}$ is the phenotypic variance, and $\mathrm{n}$ was set equal to the number of daughters for FHL, the number of inseminated daughters for $\mathrm{NR} \mathrm{m}_{\mathrm{m}}$, and the number of daughters with a calving for $\mathrm{DYS}_{\mathrm{m}}$ and $\mathrm{STI}_{\mathrm{m}}$. For $\mathrm{DYS}_{\mathrm{d}}$ and $\mathrm{STI}_{\mathrm{d}}$, n was set equal to the number of calvings descending from the bull under consideration.

In the analysis of $\mathrm{NR}_{\mathrm{p}}$, the inverse of the variance of a repeated own performance of the bull served as a weighting factor:

$$
w^{-1}=\left(\frac{1+h^{2}(n-1}{n}\right) \cdot \sigma_{p}^{2}
$$

where $\mathrm{n}$ is the number of inseminations of each sire.

The variance of the first lactation DYD for SCC from the test-day model serving as weighting factor for the analysis of SCC was assumed to be

$$
w^{-1}=\left(\frac{s^{2}+\left(1-s^{2}-h^{2}\right) \cdot(n-1)}{n}\right) \cdot \sigma_{p}^{2}
$$

where $\mathrm{s}^{2}$ is the repeatability of test day SCC within the first lactation and $\mathrm{n}$ is the number of daughters.

The program BIGMAP (Reinsch, 1999) determined the most likely marker haplotypes of each sire by a procedure similar to that described by Knott et al. (1996). These most likely marker haplotypes were taken to calculate transmission probabilities of paternal chromosomes to sons. A hypothesis test for the presence of a linked QTL 
Table 2. Distribution of markers and marker intervals across chromosomes

\begin{tabular}{|c|c|c|c|}
\hline BTA & Markers & Length (cM) & $\begin{array}{l}\text { Average marker } \\
\text { interval }(\mathrm{cM})\end{array}$ \\
\hline 1 & 14 & 190.5 & 14.7 \\
\hline 2 & 11 & 155.2 & 15.5 \\
\hline 3 & 14 & 140.9 & 10.8 \\
\hline 4 & 9 & 163.0 & 20.4 \\
\hline 5 & 10 & 136.9 & 15.2 \\
\hline 6 & 10 & 127.7 & 14.2 \\
\hline 7 & 10 & 140.2 & 15.6 \\
\hline 8 & 11 & 146.0 & 14.6 \\
\hline 9 & 5 & 93.0 & 23.3 \\
\hline 10 & 8 & 95.0 & 13.6 \\
\hline 11 & 12 & 113.0 & 10.3 \\
\hline 12 & 9 & 121.6 & 15.2 \\
\hline 13 & 13 & 142.0 & 11.8 \\
\hline 14 & 8 & 125.0 & 17.9 \\
\hline 15 & 10 & 109.2 & 12.1 \\
\hline 16 & 8 & 95.0 & 13.6 \\
\hline 17 & 9 & 92.0 & 11.5 \\
\hline 18 & 7 & 117.5 & 19.6 \\
\hline 19 & 12 & 130.1 & 11.8 \\
\hline 20 & 5 & 71.0 & 17.8 \\
\hline 21 & 9 & 88.0 & 11.0 \\
\hline 22 & 6 & 83.5 & 16.7 \\
\hline 23 & 15 & 84.0 & 6.0 \\
\hline 24 & 8 & 97.0 & 13.9 \\
\hline 25 & 5 & 73.0 & 18.3 \\
\hline 26 & 5 & 49.0 & 12.3 \\
\hline 27 & 8 & 53.4 & 7.6 \\
\hline 28 & 5 & 35.0 & 8.8 \\
\hline 29 & 5 & 64.4 & 16.1 \\
\hline $\mathrm{X} / \mathrm{Y}_{\mathrm{ps}}$ & 2 & 9.0 & 9.0 \\
\hline Total & 263 & 3132.1 & 14.0 \\
\hline
\end{tabular}

was performed at every $\mathrm{cM}$ on each autosome and the pseudoautosomal region of the sex chromosomes. Test statistic was the F-ratio of pooled mean squares due to regression within grandsires to residual mean square. The peak of the test statistic on a chromosome was considered to be the most likely position of a QTL. Chromosomewise and genomewise significance thresholds were determined by a permutation procedure (Churchill and Doerge, 1994). For each trait separately, significance thresholds were determined for each chromosome by shuffling trait data randomly within sons of each family 10,000 times. Applying the same strategy, genomewise significance thresholds were calculated by a permutation test for each trait separately.

\section{RESULTS}

The genetic marker map covered $3132 \mathrm{cM}$ of the bovine genome across all autosomes and the pseudoautosomal region of the sex chromosomes (Table 2). The average marker interval per chromosome is uniformly distributed across the genome and ranged from $6.0 \mathrm{cM}$ (BTA23) to $23.3 \mathrm{cM}$ (BTA9) with a genomewide mean of $14 \mathrm{cM}$. Informativity of markers is documented in Thomsen et al.
(2000). Thomsen et al. (2000) showed, that the marker map is in good agreement with previously published linkage maps (Barendse et al., 1997, Kappes et al., 1997), and that there are no discrepancies of marker order for chromosomes with indication of QTL in our study.

Applying a genomewise threshold of $10 \%$ error, a QTL for $\mathrm{DYS}_{\mathrm{m}}$ on position $93 \mathrm{cM}$ on BTA8 $\left(\mathrm{P}_{\text {genomewise }}=0.08\right)$ and a QTL for SCC on position $117 \mathrm{cM}$ on BTA18 ( $\mathrm{P}_{\text {genome- }}$ wise $=0.058$ ) were found (Figures 1 and $2 \mathrm{a}$ ). All functional traits for all positions of peaks of the test statistic with $\mathrm{F}$ values exceeding thresholds for 5\% chromosomewise error are listed in Table 3. For length of functional life, putative QTL were found on BTA2 and BTA18. Putative QTL for SCC were detected on BTA7, 10, and 27. For $\mathrm{DYS}_{\mathrm{d}}$, chromosomewise-significant QTL were localized on BTA7, 10, and 18. Putative QTL for $\mathrm{STI}_{d}$ were identified on BTA6, 7, 10, 13, and 18. On BTA8, 10, 18, and $\mathrm{X} / \mathrm{Y}_{\mathrm{ps}}$ QTL for $\mathrm{DYS}_{\mathrm{m}}$ as well as for $\mathrm{STI}_{\mathrm{m}}$ were found. For nonreturn rates $90 \mathrm{~d}$, representing fertility traits, putative QTL on BTA 18 and X/Y $\mathrm{ps}_{\mathrm{ps}}$ (maternal effect) and BTA10 and 18 (paternal effect) were detected.

On five chromosomes, more than one QTL for functional traits with 5\% chromosomewise significance was detected (BTA 7, 8, 10, 18, and $\mathrm{X} / \mathrm{Y}_{\mathrm{ps}}$ ). A strong coincidence of QTL influencing DYS and STI was observed for maternal as well as for direct effects in different families. Additionally, the peak position of the test statistic on chromosomes with indication of QTL was almost identical for DYS and STI. The identity of the peak positions corresponds to the observed similar shape of the test statistic across families for DYS and STI traits (e.g. figures $2 \mathrm{a}$ and $2 \mathrm{~b}$ ). However, the identity of the maximum of the test statistic was not only observed when the traits $\mathrm{DYS}_{\mathrm{m}}$ and $\mathrm{STI}_{\mathrm{m}}$ on the one hand and $\mathrm{DYS}_{\mathrm{d}}$ and $\mathrm{STI}_{\mathrm{d}}$ on the other hand were compared. On several chromosomes, sets of further traits displayed closely neighbored or identical positions of the maximum of the test statistic: $\mathrm{BTAX} / \mathrm{Y}_{\mathrm{ps}}\left(\mathrm{DYS}_{\mathrm{m}}-\mathrm{STI}_{\mathrm{m}}-\mathrm{NR90}_{\mathrm{m}}\right), \mathrm{BTA10}(\mathrm{SCC}-$ NR90 ${ }_{\mathrm{p}}$ ), and BTA18 $\left(\mathrm{STI}_{\mathrm{m}}-\mathrm{NR}_{\mathrm{m}}-\mathrm{DYS}_{\mathrm{d}}-\mathrm{FHL}-\mathrm{SCC}\right.$ - NR90 , see Table 3).

\section{DISCUSSION}

In our study, the genetic markers were almost equally distributed over the whole genome-including the pseudoautosomal region of the $\mathrm{X} / \mathrm{Y}$ chromosomes, which was not included in previous studies investigating QTL for functional traits. The average marker interval $(14 \mathrm{cM})$ in the experiment fulfills requirements for QTL mapping at the level of an initial whole genome scan. Compared to other studies (e.g. Schrooten et al., 2000, Klungland et al., 2001), the median number of trait observations per sire was very high, which should indicate a relatively high reliability of breeding values/DYD of the sires. 


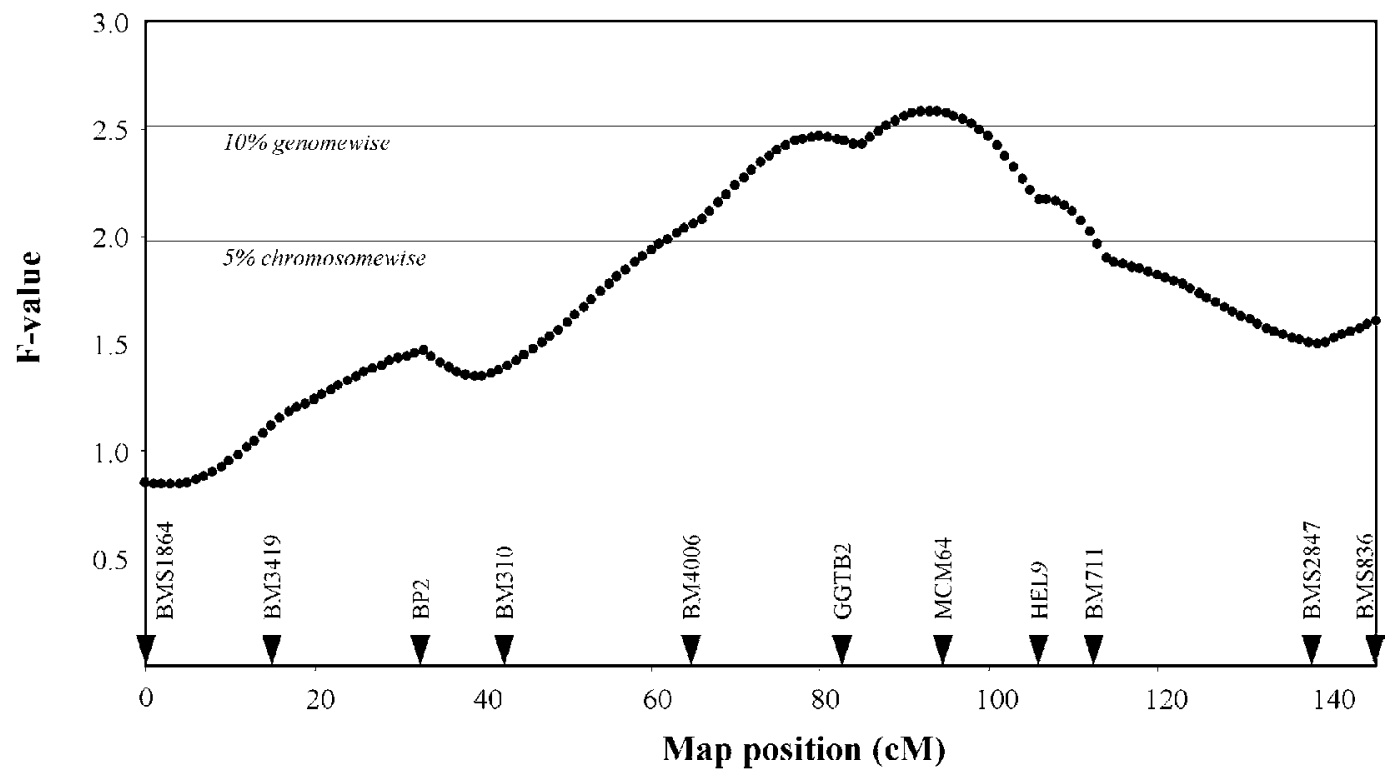

Figure 1. Profile of the test statistic of a regression analysis across families testing for the presence of a linked QTL for DYS $\mathrm{m}$ on BTA8. $10 \%$ genomewise and $5 \%$ chromosomewise significance level is indicated.

Up to now there has been no or only very limited QTL mapping for functional traits in dairy cattle. To prevent missing true QTL because of conservative tests, we applied the relatively large threshold of $10 \%$ genomewise significance in this initial study. To further identify and localize putative QTL for functional traits, we also determined chromosomal positions with chromosomewise significance $<5 \%$.

Applying a threshold of 5\% chromosomewise significance, 12 QTL were expected given the number of trait $\times$ chromosome combinations $(8 \times 30)$. The actual number of QTL detected in this study at a 5\% chromosomewise threshold is 26 and exceeds the average expected number of false positives indicating, that at least half of the detected putative QTL should be true. However, the observation, that many of our results confirm previous studies on related traits indicates an even higher number of true QTL in our study.

Calving difficulties and stillbirth (maternal effect). Applying the 5\% threshold of chromosomewise error, a QTL for calving difficulties and stillbirth (maternal effect; $\mathrm{DYS}_{\mathrm{m}} ; \mathrm{STI}_{\mathrm{m}}$ ) is detected in the middle part of BTA8 (Table 3). Schrooten et al. (2000) found an indication of suggestive QTL for size and stature in a similar chromosomal region on BTA8. Size and stature of the dam may have an impact on the delivery of the calf (Bellows et al., 1971).

On BTA18, Ashwell et al. (1998b) found an indication of a locus with impact on strength and thurl width, which may affect calving ease of a cow (Bellows et al., 1971). The position of the significant marker of their study
(BM2078) is close to peaks of our test statistic for $\mathrm{DYS}_{\mathrm{m}}$ and $\mathrm{STI}_{\mathrm{m}}$ on BTA18. The test statistic for $\mathrm{DYS}_{\mathrm{m}}$ and $\mathrm{STI}_{\mathrm{m}}$ on BTA18 displayed two peaks: one in the middle part of the chromosome, which is highest for DYS $m$, and one in the telomeric region, which is highest in the test statistic for $\mathrm{STI}_{\mathrm{m}}$. It is not clear whether this represents one or two QTL.

$\mathrm{BTAX} / \mathrm{Y}_{\mathrm{ps}}$ is not considered in previous studies of functional and type traits in dairy cattle. However, our results about putative QTL for $\mathrm{DYS}_{\mathrm{m}}, \mathrm{STI}_{\mathrm{m}}$ and $\mathrm{NR}_{\mathrm{m}}$ on $\mathrm{BTAX} / \mathrm{Y}_{\mathrm{ps}}$ underline that this genome region should be included into QTL mapping studies.

Nonreturn rate of $90 \mathrm{~d}$ (maternal effect). The putative QTL for $\mathrm{NR}_{\mathrm{m}}$ on BTA18 had not been identified in previous studies. However, results for DYS $\mathrm{S}_{\mathrm{m}}$ and $\mathrm{STI}_{\mathrm{m}}$ provided by our study and mapping results for SCC of others (Ashwell et al., 1997; Schrooten et al., 2000) may add further indication of this putative QTL, as calving difficulties as well as mastitis have been proven to be reasons for decreased female fertility (Emanuelson and Oltenacu, 1998; Schrick et al., 2001).

Calving difficulties and stillbirth (direct effect). Indication of QTL for stillbirth (direct effect; $\mathrm{STI}_{d}$ ) was found on BTA6, which is in agreement with results from Schrooten et al. (2000), who found indication of a QTL for calving ease in the same chromosomal region at 44 cM. Additionally, Schrooten et al. (2000) mapped QTL for size and dairy character in the proximal region of BTA6; both traits may influence delivery of a calf. The putative QTL for $\mathrm{STI}_{\mathrm{d}}$ on BTA6 is further underlined by results from Casas et al. (2000), who mapped a QTL for 
birth weight in the same chromosomal region, in which we localized the QTL for $\mathrm{STI}_{\mathrm{d}}$. Previous studies mapped QTL for traits related to $\mathrm{DYS}_{d} / \mathrm{STI}_{d}$ on BTA10 (QTL for angularity at position $12 \mathrm{cM}$; Schrooten et al., 2000) and BTA18 (QTL for strength near BM2078 in the telomeric part of the chromosome; Ashwell et al., 1998b). On BTA7 and 13, where we detected additional putative QTL for $\mathrm{DYS}_{\mathrm{d}}$ and/or $\mathrm{STI}_{\mathrm{d}}$, other studies did not describe QTL for direct effects on calving difficulties or related traits.

Nonreturn rate of $90 \mathrm{~d}$ (paternal effect). To our knowledge, no QTL for $\mathrm{NR} 0_{\mathrm{p}}$, an indicator of male fertility, have been mapped before in dairy cattle. We found putative QTL for this trait on BTA10 and BTA18.

SCC. For SCC the detection of a putative QTL on BTA7 is in agreement with results from Heyen et al. (1999) and Van Tassel et al. (2000). We confirmed the QTL position for SCC reported by Heyen et al. (1999) at the telomeric end of the chromosome, whereas Van Tassel et al. (2000) found a QTL in a single marker analysis in the middle part of the chromosome. Our QTL for SCC on BTA18 confirmed the QTL detection by Schrooten et al. (2000) and Ashwell et al. (1997) on the respective chromosome. Schrooten et al. (2000) localized a QTL for SCC in the middle part of BTA18, while Ashwell et al. (1997) found linkage of a QTL for SCC to marker BM2078 localized in the telomeric region of the chromosome. On BTA27 no QTL for SCC has been described before. Although Klungland et al. (2001) recently mapped a QTL for mastitis resistance in the middle part of BTA27 (marker interval IOBT313-BM1857) near the position where the QTL for SCC mapped in our study, they did not find any indication of a QTL for SCC in their data set. These discrepancies might reflect that clinical mastitis and SCC seem to monitor different aspects (e.g. clinical vs. subclinical infection) of udder health (Pösö and Mäntysaari, 1996). Schrooten et al. (2000) provide additional support for the existence of a locus with impact on udder health on BTA27, because they localized a QTL for udder depth on this chromosome. Udder depth is one of the type traits in dairy cattle with the strongest correlation to SCC (Lund et al., 1994).

Functional herd life. Only very few studies investigated QTL for longevity in cattle. Applying a threshold of $5 \%$ chromosomewise significance, we detected putative QTL for functional herd life on BTA2 and BTA18. Van Tassel et al. (2000), however, found a QTL for productive life on BTA2 in a single marker analysis at the telomeric end of the chromosome. For BTA18 this is the first report of a QTL for longevity. However, to compare our results with those of other studies, it has to be considered that trait definition was not identical. While Heyen et al. (1999), Ashwell et al. (1997; 1998a; 1999), and Van Tassel et al. (2000) looked at productive herd life, which measures the success of a cow to survive both voluntary and involuntary culling, in our study the length of functional herd life was investigated and is adjusted for voluntary culling due to unsatisfactory milk yield within herd. Because the definition of the traits is not identical, different genes may be responsible for their genetic variation. When looking at traits related to longevity, several studies confirming the putative QTL on BTA2 and BTA18 are found. At the position of the putative QTL for functional herd life in the middle part of BTA2, Ashwell et al. (1998b) found indication of a QTL for fore udder attachment. Additionally, Schrooten et al. (2000) localized a QTL for milking speed in the respective chromosomal region on BTA2. Milking speed and fore udder attachment are correlated to SCS and also to mastitis (Lund et al., 1994). Evidence for the putative QTL for functional herd life on BTA2 and BTA18 is further strengthened by the fact that in both chromosomal regions the test statistic for SCC was significant at a $10 \%$ genomewise (BTA18) or chromosomewise (BTA2; data not shown) level. Besides infertility, mastitis is the main cause for involuntary culling in the German Holstein population (Rinderproduktion in der Bundesrepublik Deutschland 1999; 2000). Neerhof et al. (2000) found a genetic correlation of -0.4 between the risk of being culled and the national evaluations of the bulls for mastitis resistance in Danish Black and White dairy cows. Additionally, the strongest genetic correlations were found between udder traits (fore udder attachment, udder depth) and longevity when looking at the relation between type traits and yield adjusted herd life (Vukasinovic et al., 1995; Larroque and Ducrocq, 2001). Therefore, the locus contributing to genetic variation of SCC may also influence the length of functional life, as cows with an increased incidence of mastitis may have an increased risk of reduced herd life due to involuntary culling. This finding supports the hypothesis that loci with influence on udder traits and/or mastitis may also contribute to genetic variance of longevity.

In our study, the coincidence of QTL localization for several functional traits in identical chromosomal regions raised the question about the underlying mechanisms. Either a single gene with pleiotropic effects on several correlated traits or several tightly linked QTL could result in coincidence of QTL localization for several functional traits. Further investigations, including an increased marker density in the respective chromosomal regions as well as additional statistical analyses (e.g. multivariate analyses), will be necessary to discriminate between the two hypotheses.

There are several reports about unfavorable genetic correlations between milk performance traits and functional traits (Simianer et al., 1991; Castillo-Juarez et al., 2000). However, the chromosomal positions of QTL for functional traits in this study did not show overlaps with 
KÜHN ET AL.

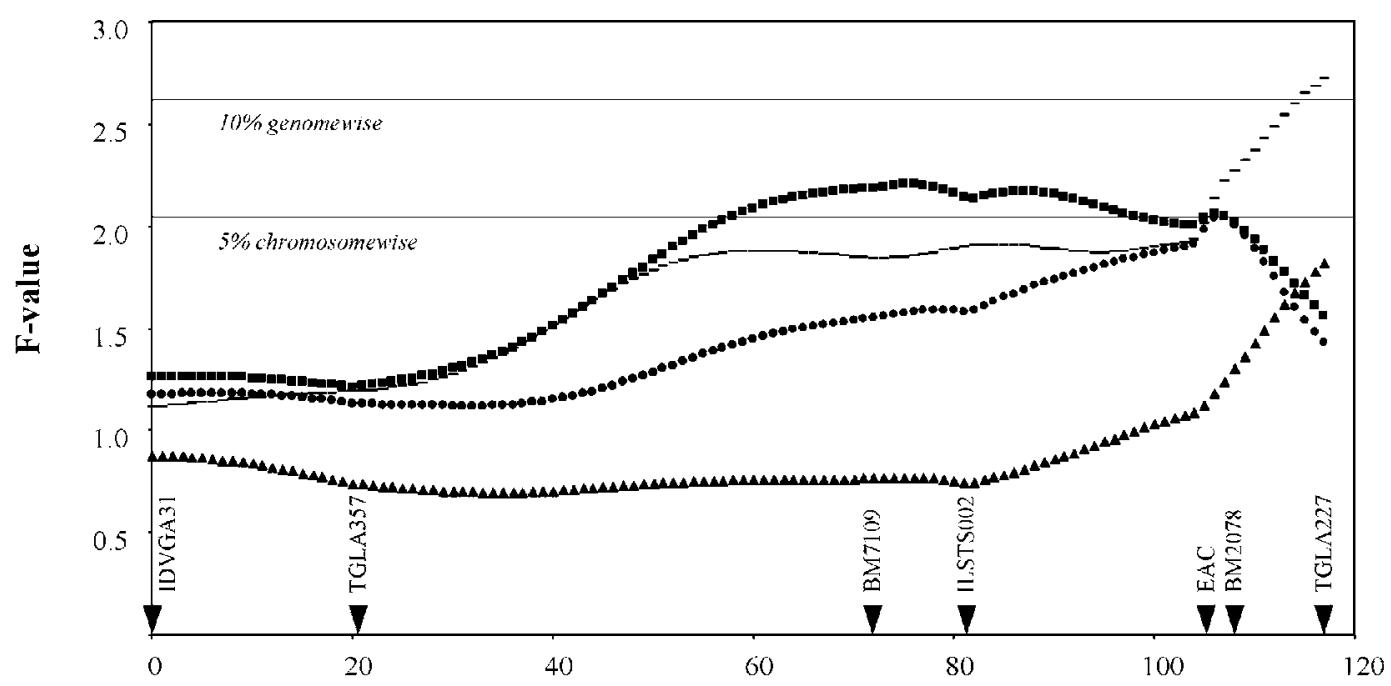

Map position (cM)

(a)

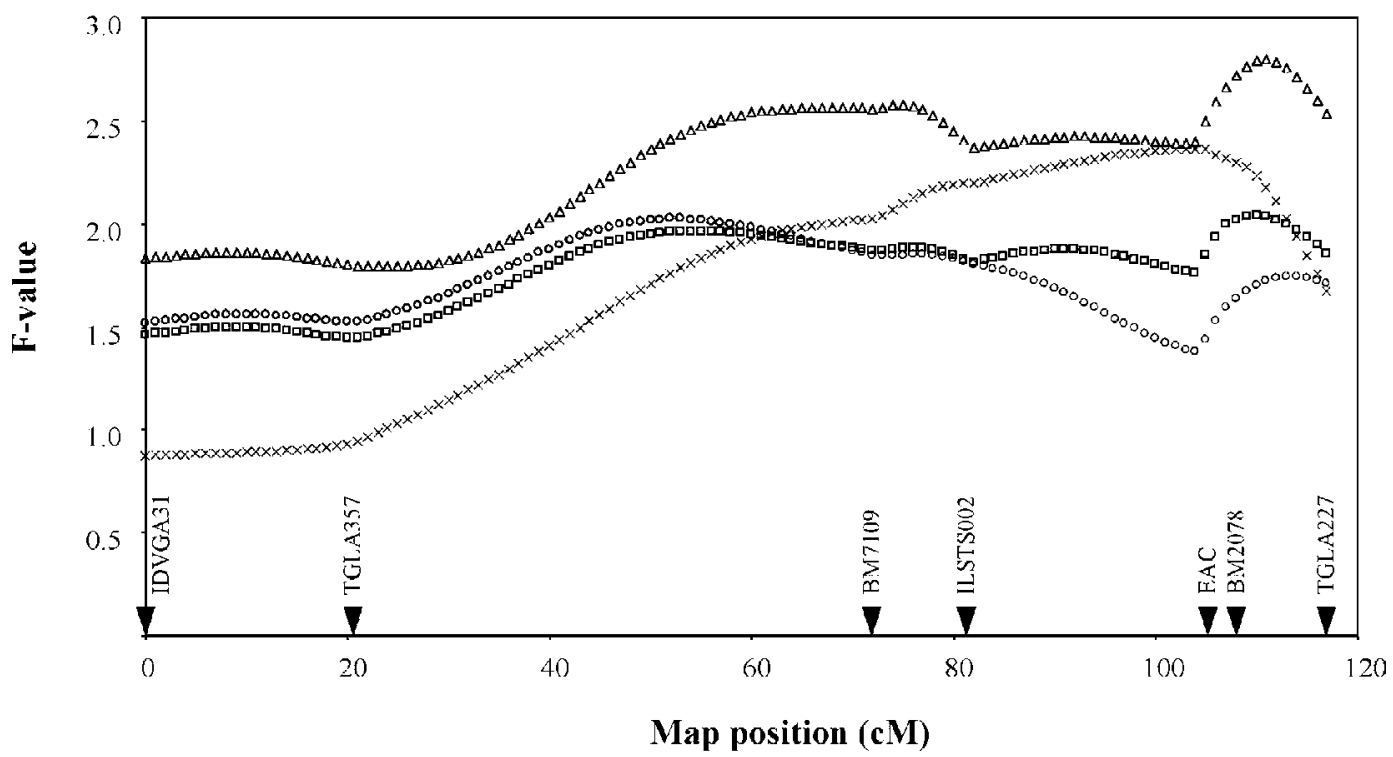

(b)

Figure 2. Profile of the test statistic of a regression analysis across families testing for the presence of a linked QTL for eight functional

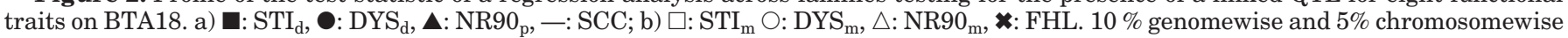
significance level for SCC is indicated.

genomic positions of QTL for milk performance traits in Holsteins, except for $\mathrm{STI}_{d}$ on BTA6. Especially in the proximal part of BTA14, where a missense mutation in the DGAT1 gene with a major effect on milk performance traits was identified (Grisart et al., 2002), no QTL for functional traits was detected. Nevertheless, the lack of coincidence of QTL for milk performance traits and QTL for functional traits is no proof that unfavorably corre- lated effects on functional traits can be excluded for the previously detected QTL for milk performance traits. However, it may be assumed that if the correlated effects existed, their effect should be smaller than for those QTL for functional traits described in this report. Absence of unfavorably correlated effects on performance and functional traits would significantly increase efficiency of selection on functional traits in MAS breeding schemes, 
Table 3. Results of QTL analysis across families. Positions of QTL are indicated in cM and by flanking marker interval. Chromosomal significance of the QTL is given in brackets and italics.

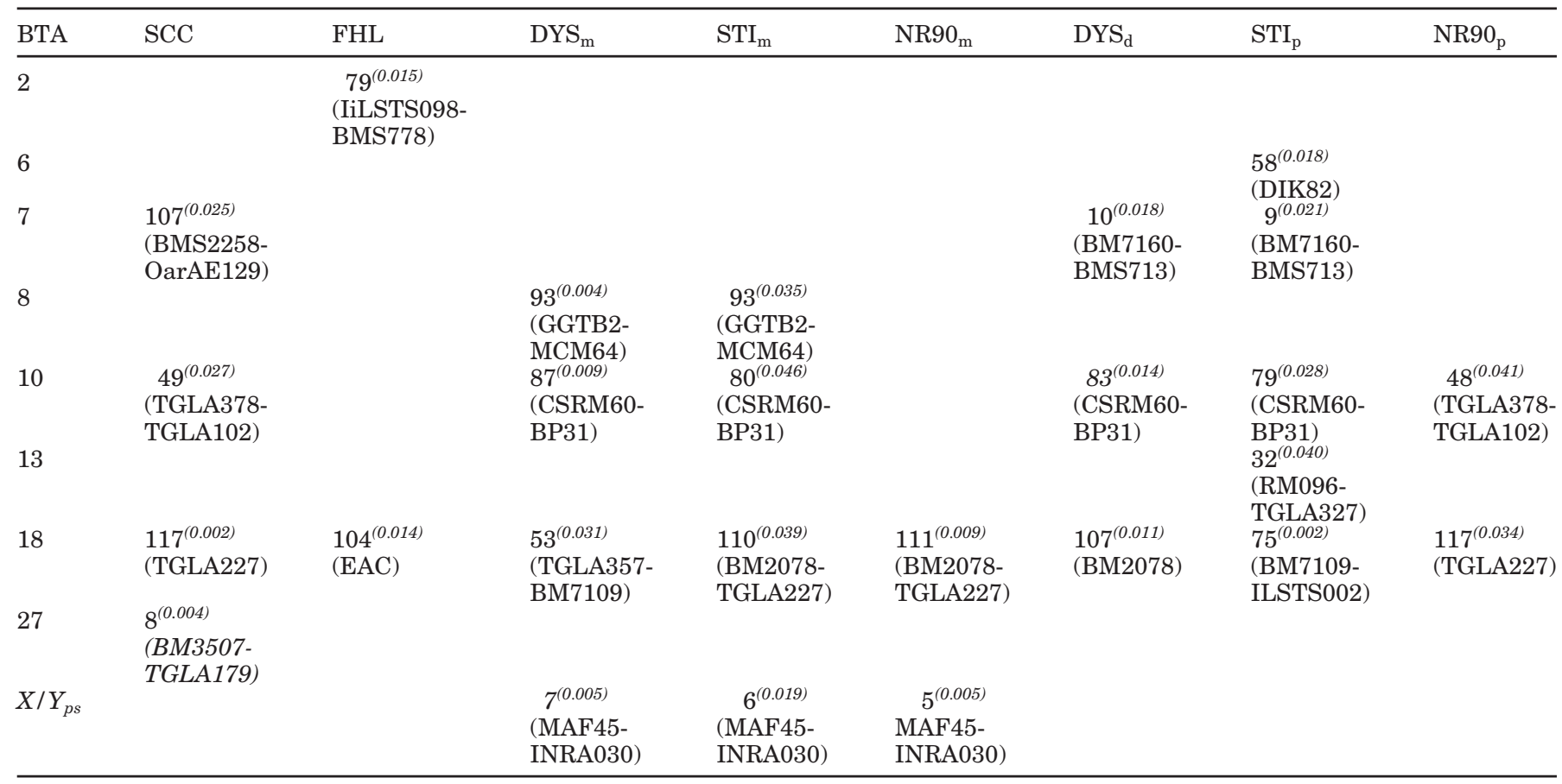

because no undesirable effects on performance traits have to be taken into account.

\section{CONCLUSIONS}

Information on prevalence, position, and effects of QTL for the target traits is required to implement markerassisted selection (MAS) in dairy breeding programs. In our study, we showed that a QTL for dystocia (maternal effect) on BTA8 and a QTL for SCC on BTA18 are segregating in the German Holstein population. Further putative QTL for dystocia (direct and maternal effects), stillbirth (direct and maternal effects), NR90 (paternal and maternal effects), SCC, and functional herd life could be localized in distinct chromosomal regions. However, due to the relatively large statistical threshold values in our study, those QTL without confirmation have to be investigated in further studies. Five chromosomes (BTA7, 8, 10,18 , and $\mathrm{X} / \mathrm{Y}_{\mathrm{ps}}$ ) harbored QTL for more than one functional trait. Coincidence of peaks of test statistic for functional herd life and SCC on BTA2 and BTA18 together with results from previous reports about QTL for udder traits in the respective chromosomal areas suggest that loci with influence on udder traits and/or udder health may also contribute to genetic variance of longevity. Regarding practical application for dairy cattle breeding, the detection of QTL for several functional traits indicates that it will be principally possible to use MAS for these traits, which are of increasing economic importance in the German Holstein population.

\section{ACKNOWLEDGMENTS}

The authors thank the Arbeitsgemeinschaft Deutscher Rinderzüchter for their cooperation and the German cattle breeding organizations for technical and financial support. The study was financially supported by the German Federal Ministry of Education and Research (Project Nr. 0311020A).

\section{REFERENCES}

Ashwell, M. S., C. E. Rexroad, R. H. Miller, P. M. Vanraden, and Y. Da. 1997. Detection of loci affecting milk production and health traits in an elite US Holstein population using microsatellite markers. Anim. Genet. 28:216-222.

Ashwell, M. S., Y. Da, C. P. Van Tassell, P. M. Vanraden, R. H. Miller, and C. E. Rexroad. 1998a. Detection of putative loci affecting milk production and composition, health, and type traits in a United States Holstein population. J. Dairy Sci. 81:3309-3314.

Ashwell, M. S., Y. Da, P. M. Vanraden, C. E. Rexroad, and R. H. Miller. 1998b. Detection of putative loci affecting conformational type traits in an elite population of United States Holsteins using microsatellite markers. J. Dairy Sci. 81:1120-1125.

Ashwell, M. S., and C. P. Van Tassell. 1999. Detection of putative loci affecting milk, health, and type traits in a US Holstein population using 70 microsatellite markers in a genome scan. J. Dairy Sci. 82:2497-2502.

Barendse, W., D. Vaiman, S. J. Kemp, Y. Sugimoto, S. M. Armitage, J. L. Williams, H S. Sun, A. Eggen, M. Agaba, S. A. Aleyasin, M. Band, M. D. Bishop, J. Buitkamp, K. Byrne, F. Collins, L. Cooper, 
W. Coppetiers, B. Denys, R. D. Drinkwater, K. Easterday, C. Elduque, S. Ennis, G. Erhardt, L. Ferretti, N. Flavin, Q. Gao, M. Georges, R. Gurung, B. Harlizius, G. Hawkins, J. Hetzel, T. Hirano, D. Hulme, C. Jorgensen, M. Kessler, B. W. Kirkpatrick, B. Konfortov, S. Kostia, C. Kuhn, J. A. Lenstra, H. Leveziel, H. A. Lewin, B. Leyhe, L. Li, I. M. Burriel, R. A. McGraw, J. R. Miller, D. E. Moody, S. S. Moore, S. Nakane, I. J. Nijman, I. Olsaker, D. Pomp, A. Rando, M. Ron, A. Shalom, A. J. Teale, U. Thieven, B. G. D. Urquhart, D.-I. Vage, A. Van de Weghe, S. Varvio, R. Velmala, J. Vilkki, R. Weikard, C. Woodside, J. E. Womack, M. Zanotti, and P. Zaragoza. 1997. A medium-density genetic linkage map of the bovine genome. Mamm. Genome 8:21-28.

Bellows, R. A., R. E. Short, D. C. Anderson, B. W. Knapp, and O. F. Pahnish. 1971. Cause and effect relationships associated with calving difficulty and calf birth weight. J. Anim. Sci. 33:407-412.

Casas, E., S. D. Shackelford, J. W. Keele, R. T. Stone, S. M. Kappes, and M. Koohmaraie. 2000. Quantitative trait loci affecting growth and carcass composition of cattle segregating alternate forms of myostatin. J. Anim. Sci. 78:560-569.

Castillo-Juarez, H., P. A. Oltenacu, R. W. Blake, C. E. McCulloch, and E. G. Cienfuegos-Rivas. 2000. Effect of herd environment on the genetic and phenotypic relationships among milk yield, conception rate, and SCS in Holstein cattle. J. Dairy Sci. 83:807-814.

Churchill, G. A., and R. W. Doerge. 1994. Empirical threshold values for quantitative trait mapping. Genet.138:963-971.

Ducrocq, V., and J. Soelkner. 1998. The Survival Kit- a Fortran package for the analysis of survival data. Proc. 6th World Congr. Genet. Appl. Livest. Prod., Armidale, Australia 27:447-448.

Dürr, J. W., H. G. Monardes, R. I. Cue, and J. C. Philpot. 1997. Culling in Quebec Holstein herds. 1. Study of phenotypic trends in herd life. Can. J. Anim. Sci. 77:593-600.

Emanuelson, U., and P. A. Oltenacu. 1998. Incidences and effects of diseases on the performance of Swedish dairy herds stratified by production. J. Dairy Sci. 81:2376-2382.

Essl, A. 1998. Longevity in dairy cattle breeding: a review. Livest. Prod. Sci. 57:79-89.

Georges, M., D. Nielsen, M. J. Mackinnon, A. Mishra, R. Okimoto, A. T. Pasquino, L. S. Sargeant, A. Sorensen, M. R. Steele, X. Zhao, J. E. Womack, and I. Hoeschele. 1995. Mapping quantitative trait loci controlling milk production in dairy cattle by exploiting progeny testing. Genetics 139:907-920.

Green, P., K. Falls, and S. Crooks. 1990. Documentation of CRI-MAP, Version 2.4. Washington University School of Medicine, St. Louis, MO.

Grisart, B., W. Coppieters, F. Farnir, L. Karim, C. Ford, P. Berzi, N. Cambisano, M. Mni, S. Reid, P. Simon, R. Spelman, M. Georges, and R. Snell. 2002. Positional candidate cloning of a QTL in dairy cattle: identification of a missense mutation in the bovine DGAT1 gene with major effect on milk yield and composition. Genome Res. 12:222-231.

Groen, A. F., T. Steine, J. J. Colleau, J. Pedersen, J. Pribyl, and N. Reinsch. 1997. Economic values in dairy cattle breeding, with special reference to functional traits. Report of an EAAP-working group. Livest. Prod. Sci. 49:1-21.

Heyen, D. W., J. I. Weller, M. Ron, M. Band, J. E. Beever, E. Feldmesser, Y. Da, G. R. Wiggans, P. M. Vanraden, and H. A. Lewin. 1999. A genome scan for QTL influencing milk production and health traits in dairy cattle. Physiological Genomics 1:165-175.

Kappes, S. M., J. W. Keele, R. T. Stone, R. A. McGraw, T. S. Sonstegard, T. P. L. Smith, N. L. Lopez-Corrales, and C. W. Beattie. 1997. A second-generation linkage map of the bovine genome. Genome Res. 7:235-249.

Klungland, H., A. Sabry, B. Heringstad, H. G. Olsen, L. Gomez-Raya, D. I. Vage, I. Olsaker, J. Odegard, G. Klemetsdal, N. Schulman, J. Vilkki, J. Ruane, M. Aasland, K. Ronningen, and S. Lien. 2001. Quantitative trait loci affecting clinical mastitis and somatic cell count in dairy cattle. Mamm. Genome 12:837-842.
Knott, S. A., J. M. Elsen, and C. S. Haley. 1996. Methods for multiplemarker mapping of quantitative trait loci in half-sib populations. Theor. Appl. Genet. 93:71-80.

Kühn, C., G. Freyer, R. Weikard, T. Goldammer, and M. Schwerin. 1999. Detection of QTL for milk production traits in cattle by application of a specifically developed marker map of BTA6. Anim. Genet. 30:333-340.

Larroque, H., and V. Ducroque. 2001. Relationships between type and longevity in the Holstein breed. Genet., Sel., Evol. 33:39-59.

Lund, T., F. Miglior, J. C. M. Dekkers, and E. B. Burnside. 1994. Genetic relationships between clinical mastitis, somatic cell count, and udder conformation in Danish Holsteins. Livestock Prod. Sci. 39:243-251.

Neerhof, H. J., P. Madsen, V. P. Ducrocq, A. R. Vollema, J. Jensen, and I. R. Korsgaard. 2000. Relationships between mastitis and functional longevity in Danish black and white dairy cattle estimated using survival analysis. J. Dairy Sci. 83:1064-1071.

Pösö, J. and E. A. Mäntysaari. 1996. Relationships between clinical mastitis, SCS, and production for the first three lactations of Finnish Ayrshire. J. Dairy Sci. 79:1284-1291.

Reents, R. 1995. Zuchtwertschätzung auf Zellzahl. Züchtungskunde 67:461-466.

Reinsch, N. 1999. A multiple-species, multiple-project database for genotypes at codominant loci. J. Anim. Breed. Genet. 116:425-435.

Rinderproduktion in der Bundesrepublik Deutschland 1999. 2000. Arbeitsgemeinschaft Deutscher Rinderzüchter, Adenauerallee 174, D-53113 Bonn, Germany.

Royal, M. D., A. O. Darwash, A. P. E. Flint, R. Webb, and J. A. Woolliams. 2000. Declining fertility in dairy cattle: changes in traditional and endocrine parameters of fertility. Anim. Sci. 70:487-501.

Schrick, F. N., M. E. Hockett, A. M. Saxton, M. J. Lewis, H. H. Dowlen, and S. P. Oliver. 2001. Influence of subclinical mastitis during early lactation on reproductive parameters. J. Dairy Sci. 84:1407-1412.

Schrooten, C., H. Bovenhuis, W. Coppieters, and J. A. M. Van Arendonk. 2000. Whole genome scan to detect quantitative trait loci for conformation and functional traits in dairy cattle. J. Dairy Sci. 83:795-806.

Simianer H., H. Solbu, and L. R. Schaeffer. 1991. Estimated genetic correlations between disease and yield traits in dairy cattle. J. Dairy Sci. 74:4358-4365.

Thomsen, H., N. Reinsch, N. Xu, C. Looft, S. Grupe, C. Kühn, G. A. Brockmann, M. Schwerin, B. Leyhe-Horn, S. Hiendleder, G. Erhardt, I. Medjugorac, I. Russ, M. Förster, B. Brenig, F. Reinhardt, R. Reents, J. Blümel, G. Averdunk, and E. Kalm. 2000. A male bovine linkage map for the ADR granddaughter design. J. Anim. Breed. Genet. 117:289-306.

Vanraden, P. M. and G. R. Wiggans, 1991. Derivation, calculation, and use of National Animal Model information. J. Dairy Sci. 74:2737-2746.

Van Tassell, C. P., M. S. Ashwell, and T. S. Sonstegard. 2000. Detection of putative loci affecting milk, health, and conformation traits in a US Holstein population using 105 microsatellite markers. J. Dairy Sci. 83:1865-1872.

Vollema, A. R., S. Van Der Beek, A. G. F. Harbers, and G. De Jong. 2000. Genetic evaluation for longevity of Dutch dairy bulls. J. Dairy Sci. 83:2629-2639.

Vukasinovic, N., J. Moll, and N. Künzi. 1995. Genetic relationships among longevity, milk production, and type traits in Swiss Brown cattle. Livest: Prod. Sci. 41:11-18.

Weikard, R., T. Goldammer, C. Kühn, W. Barendse, and M. Schwerin. 1997. Targeted development of microsatellite markers from the defined region of bovine chromosome 6q21-31. Mamm. Genome 8:836-840.

Weller, J. I., Y. Kashi, and M. Soller. 1990. Power of daughter and granddaughter designs for determining linkage between marker loci and quantitative trait loci in dairy cattle. J. Dairy Sci. 73:2525-2537. 